DE

M E D I C I N A

T R O P I C A L

$\mathrm{DE}$

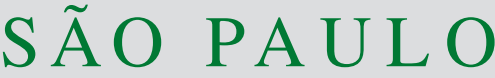

JOURNAL OF THE SÃO PAULO INSTITUTE OF TROPICAL MEDICINE

(1)Fundação Oswaldo Cruz, Instituto Oswaldo Cruz, Laboratório de Inovações em Terapias, Ensino e Bioprodutos, Rio de Janeiro, Rio de Janeiro, Brazil

(2)Fundação Oswaldo Cruz, Escola Nacional de Saúde Pública Sérgio Arouca, Departamento de Saneamento e Saúde Ambiental, Rio de Janeiro, Rio de Janeiro, Brazil

(3)Fundação Oswaldo Cruz, Instituto Oswaldo Cruz, Rio de Janeiro, Rio de Janeiro, Brazi

Correspondence to: Caroline Ferraz Ignacio

Fundação Oswaldo Cruz, Instituto Oswaldo Cruz, Laboratório de Inovações em Terapias, Ensino e Bioprodutos, Av. Brasil, 4365, Pavilhão Lauro Travassos, Sala 18, CEP 21040-900, Manguinhos, Rio de Janeiro, RJ, Brazil

Tel: +5521 2562-1054

E-mail: cfignacio@yahoo.com, caroline.ignacio@ioc.fiocruz.br

Received: 6 January 2017

Accepted: 31 March 2017

\section{Socioenvironmental conditions and intestinal parasitic infections in Brazilian urban slums: a cross-sectional study}

\author{
Caroline Ferraz Ignacio', Milena Enderson Chagas da Silva1, Natasha \\ Berendonk Handam², Maria de Fatima Leal Alencar ${ }^{1}$, Adriana Sotero- \\ Martins $^{2}$, Martha Macedo de Lima Barata ${ }^{3}$, Antonio Henrique Almeida de \\ Moraes Neto
}

\section{ABSTRACT}

Intestinal parasitic infections (IPIs) are neglected diseases with limited data regarding prevalence in Brazil and many other countries. In increasingly urban societies, investigating the profile and socioenvironmental determinants of IPIs in the general population of slum dwellers is necessary for establishing appropriate public policies catered to these environments. This study assessed the socioenvironmental conditions and prevalence of IPIs in slums of Rio de Janeiro, RJ State, Brazil. Methods: A cross-sectional study covering an agglomeration of urban slums was conducted between 2015 and 2016 using participants observation, a socioeconomic survey, and the spontaneous sedimentation method with three slides per sample to analyze fresh stool specimens $(n=595)$ searching for intestinal parasites. Results: Endolimax nana $(n=95,16.0 \%)$ and Entamoeba coli $(n=65,10.9 \%)$ were the most frequently identified agents, followed by Giardia intestinalis $(n=24,4.0 \%)$ and Ascaris lumbricoides ( $n=11,1.8 \%$ ). Coinfections caused by E. nana and E. histolytica/dispar and by Entamoeba coli/A. lumbricoides were significant. The use of piped water as drinking water, the presence of A. lumbricoides, and contamination with coliform bacteria and Escherichia coli were more common in major area (MA) 1. Children (0-19 years) had a greater chance of living in poverty (OR 3.36; 95\% CI: $2.50-4.52 ; p<0.001)$ which was pervasive. The predominance of protozoa parasites suggests that a one-size-fits-all approach focusing on preventive chemotherapy for soil-transmitted helminths is not appropriate for all communities in developing countries. It is important that both residents and health professionals consider the socioenvironmental conditions of urban slums when assessing intestinal parasitic infections for disease control and health promotion initiatives.

KEYWORDS: Urban health. Protozoan infections. Neglected diseases. Poverty. Tropical medicine.

\section{INTRODUCTION}

Intestinal parasitic infections (IPIs) are neglected diseases caused by helminths or protozoa affecting more than two billion people, or about one in four people ${ }^{1}$. Although they present a wide geographical distribution, presence, duration and intensity of these infections are influenced by environmental, household, nutritional and other characteristics linked to poverty ${ }^{2,3}$. IPIs are associated with a disability-adjusted life year (DALY) loss of 560,840 in the Americas and 5,266,000 globally ${ }^{4}$. In addition to the burden IPIs cause to communities, they may amplify the burden of other neglected diseases such as tuberculosis, 
enteroviruses, American tegumentary leishmaniasis and malaria, among others ${ }^{5-8}$.

In Brazil, like in many countries, limited data exist on the prevalence of IPIs since only cases of schistosomiasis in nonendemic areas must be reported ${ }^{9}$. Underreporting and limited routine screenings lead to the dependence of estimates for public health planning. Many epidemiological studies focus on rural communities or other specific populations; however, in increasingly urban societies, investigating the profile and determinants of IPIs among the general population of slum dwellers in developing countries is necessary for establishing appropriate public policies catered to these environments. To our knowledge, this is the first epidemiological study on IPIs conducted in this large urban center. Current public policies and international guidelines related to IPIs focus almost exclusively on soil transmitted helminths $(\mathrm{STH})^{10-12}$, however, many recent studies have found a shift in community profiles of IPIs from a predominance of STH to protozoans ${ }^{13-16}$. Therefore, this cross-sectional study, following the Strengthening the Reporting of Observational Studies in Epidemiology Guidelines (STROBE), assessed the socioenvironmental conditions and prevalence of IPIs in slums of Rio de Janeiro, RJ State, Brazil.

\section{METHODS}

\section{Study area and population}

The Complexo de Manguinhos (CM) is an agglomeration of 13-19 slums in Northern Rio de Janeiro, Rio de Janeiro State (RJ), Brazil (22॰52'47.04”S 4314'57.18”W) constructed over mangrove swamps. Primary healthcare is provided for CM residents by the Family Health Strategy (FHS) program, which has divided the territory into 13 communities and 5 major areas (MAs) (Figure 1). A reported 38,461 people in 12,528 families are registered in the FHS, which reports $100 \%$ coverage of the communities ${ }^{17}$. Table 1 shows major characteristics of each MA. The overall study area is characterized by overcrowding, clandestine electrical and plumbing connections to official networks, free-roaming animals (e.g. dogs, rats and cats), and accumulation of trash despite regular collection. With the exception of MA1, these communities suffer from high levels of violence associated with drug trafficking and in 2013 military police regained control of these communities by installing Pacifying Police Units (UPPs is the abbreviation in Portuguese). Large-scale government construction projects (PAC) in the area began

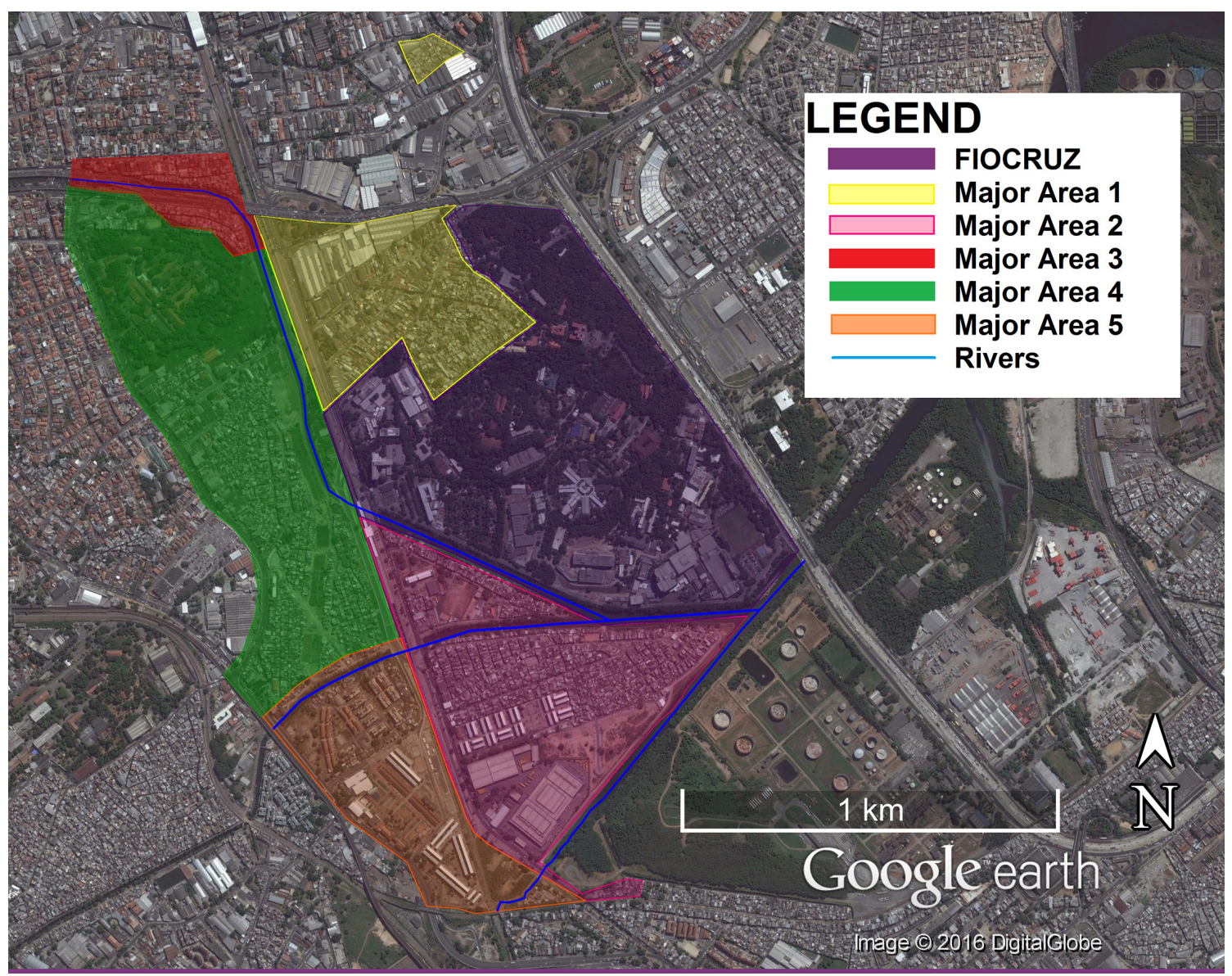

Figure 1 - Map of the Major Areas (MA) of Complexo de Manguinhos, Rio de Janeiro, Brazil 
Table 1 - Characterization of Complexo de Manguinhos (CM), Rio de Janeiro, Brazil

\begin{tabular}{|c|c|c|c|c|c|}
\hline $\begin{array}{l}\text { Major } \\
\text { Area }\end{array}$ & $\begin{array}{l}\text { N. of } \\
\text { slums }\end{array}$ & Pop. & Constructed environment & Natural environment & $\begin{array}{l}\text { Socioeconomic } \\
\text { characteristics }\end{array}$ \\
\hline 1 & 3 & 5325 & $\begin{array}{l}\text { - Some homes have yards (with trees } \\
\text { and/or other limited vegetation) } \\
\text { - In one of these slums a church } \\
\text { occupies } 2 / 3 \text { of the territory, the } \\
\text { remaining spaces exhibit extremely } \\
\text { thin alleys and verticalization of } \\
\text { homes } \\
\text { - No playing fields }\end{array}$ & $\begin{array}{l}\text { - Each community physically sepa- } \\
\text { rated from the rest of the CM } \\
\text { Highest elevation (39.6 meters) } \\
\text { - Does not border any rivers }\end{array}$ & $\begin{array}{l}\text { - Oldest, most established } \\
\text { communities of the CM } \\
\text { - Not violent } \\
\text { - No visible drug consump- } \\
\text { tion areas ("bocas de } \\
\text { fumo") }\end{array}$ \\
\hline 2 & 7 & 12201 & $\begin{array}{l}\text { - Heterogeneous housing structures } \\
\text { - Mix of streets and alleys } \\
\text { - One of these communities was } \\
\text { previously demolished and is in the } \\
\text { process of reconstruction }\end{array}$ & $\begin{array}{l}\text { - Greatest periodic flooding } \\
\text { - Borders the Faria-Timbó River, } \\
\text { Jacaré River, Cunha Canal and } \\
\text { Manguinhos Canal }\end{array}$ & - Pacifying Police Unit \\
\hline 3 & 2 & 3251 & $\begin{array}{l}\text { - Intercepted by a major highway with } \\
\text { homes underneath the highway } \\
\text { continuously demolished (by the } \\
\text { government) and rebuilt (by the } \\
\text { population) } \\
\text { - Accessible by car } \\
\text { - Predominance of streets instead of } \\
\text { alleys }\end{array}$ & $\begin{array}{l}\text { - Physically separated from the } \\
\text { rest of the CM } \\
\text { - Borders the Faria-Timbó River }\end{array}$ & $\begin{array}{l}\text { - Visible "boca de fumo"near } \\
\text { the highway }\end{array}$ \\
\hline 4 & 4 & 12690 & $\begin{array}{l}\text { - Thin alleys, limited accessibility by } \\
\text { car } \\
\text { - Verticalization of homes } \\
\text { - Visible sewage and/or water leaks } \\
\text { Many demolished and/or partially } \\
\text { demolished homes (result of PAC) }\end{array}$ & $\begin{array}{l}\text { - Periodic flooding } \\
\text { - Community gardens } \\
\text { - Presence of free-roaming swine } \\
\text { and poultry } \\
\text { - Borders the Faria-Timbó and the } \\
\text { Jacaré Rivers }\end{array}$ & $\begin{array}{l}\text { - Pacifying Police Unit } \\
\text { - Visible "bocas de fumo" }\end{array}$ \\
\hline 5 & 3 & 4994 & $\begin{array}{l}\text { - Apartment complexes } \\
\text { - Public housing for low-income fami- } \\
\text { lies } \\
\text { - Apartments originally granted } \\
\text { to veterans of the } 2^{\text {nd }} \text { World War } \\
\text { (higher income families) } \\
\text { - Heterogeneous housing structures } \\
\text { Hub of PAC interventions }\end{array}$ & - Borders the Jacaré River & $\begin{array}{l}\text { - Very heterogeneous so- } \\
\text { cioeconomic conditions of } \\
\text { families } \\
\text { - Center of public services } \\
\text { offered in the CM }\end{array}$ \\
\hline
\end{tabular}

in 2007 aiming at improving sanitation, however, PAC has provided mixed results, concentrating improvements in MA5 and worsening conditions in other MAs ${ }^{18}$.

\section{Data collection}

A cross-sectional study was conducted, between 2015 and 2016 using participant observation, interviews and a socioeconomic survey based on the Basic Questionnaire Demographic Census and the Unified Registration Form for Social Programs, validated by Moraes Neto et al. ${ }^{19-21}$. Similar socioeconomic surveys have been recently used by Srinivasan et al..$^{2}$, Sandoval et al. ${ }^{13}$, and Casavechia et al..$^{14}$. Since areas with soil were limited due to the widespread presence of concrete, soil samples were collected from public areas (e.g. soccer fields, community gardens, parks) distributed throughout the slums (convenience sampling) ( $n=22)$. Predictor variables included individual socioeconomic parameters (age, sex, educational attainment level and employment status) and household characteristics (household income, presence of toilet inside the house; drinking water source and material of household floors).

For stool sample collection, wide mouth screw capped containers with scoops were labeled and distributed to every member of the selected households while oral instructions on sample collection were provided. The research team returned on two consecutive days, when necessary, to collect the fresh samples. Some visits were interrupted by violent conflicts in the territory.

The sample size of 282 was determined considering an estimated prevalence of $25 \%$ (based on a pre-test conducted in 2010) of IPIs, a sample guarantee of 5\%, a design effect of 1 , and a $95 \%$ confidence interval. Systematic sampling started with a randomly selected house and continuing 
by approaching every twenty households, respecting the proportions of families distribution throughout the MAs. Since the study area is constantly changing, the number of households was greater than that counted by health services. Therefore, by following this sampling method, a total of 318 households were included in the study.

\section{Data analysis}

The spontaneous sedimentation method, one of the most frequently used in research on IPIs in Brazil and the method of choice within the Brazilian health system (SUS) was used with three slides per sample, to identify intestinal parasites in fresh fecal samples ${ }^{22,23,24}$. All parasitological results were provided to residents; and, those with positive samples were referred to the participating FHS clinic for treatment.

Soil samples were analyzed by spontaneous sedimentation and the adapted Baermann techniques ${ }^{22-25}$. Total coliform and Escherichia coli levels in the soil were evaluated considering the guidelines established by the municipal legislation ${ }^{26}$.

Monthly household income and number of residents were used to assign poverty levels where BRL $\$ 70.00$ per person/month was considered the extreme poverty line and BRL $\$ 170.00$ per person/month was considered the poverty line. These values coincide with the extreme poverty and poverty limits established by the Brasil Sem Miséria and Bolsa Família programs, respectively.

Data were organized within a Microsoft Access database, exported to EpiInfo 7.0 and analyzed using the $\chi^{2}$ or Fisher's exact test, when appropriate. Odds ratios (ORs) and their respective $95 \%$ confidence intervals (95\% CI) were calculated. Values of $p<0.05$ were considered statistically significant. Data were included in the multivariable analysis (logistical regression or linear regression, when applicable) if significant to the univariate analysis.

\section{Ethical Statement}

This study was approved by the Instituto Oswaldo Cruz (IOC/FIOCRUZ) Committee for Ethics in Research (CAAE 55512916.3.0000.5248), in accordance with the 1964 Helsinki declaration and its later amendments or comparable ethical standards. All study participants received an oral and written explanation of their rights, the procedures to be used and the purpose of the study in accessible language. Recruitment occurred only after obtaining written informed consent from adults and from the parents/legal guardians on behalf of minors. Each household received a copy of the Free and Informed Consent form. Information to enable the research team to contact the participants was provided, answers to the questions regarding IPIs were also provided by the research team and residents of participating households were invited to take part in a health promotion course offered by IOC/ FIOCRUZ. During home visits health education activities for the population occurred through oral explanations of IPIs, leaflets on water quality and treatment, and invitations to participate in a yearly health promotion course.

\section{RESULTS}

The study included 318 households with 1,230 residents and $595(48.4 \%)$ provided samples for analysis. Reasons provided for non-participation included: embarrassment, scheduling conflicts, constipation and violence which made the territory inaccessible to the research team; however, the profile of those that did not provide stool samples were similar, hence constituting random loss. Predictor variables are shown according to MA (Table 2). The use of piped water as the drinking source $(p<0.001)$ and the poverty levels were different among MAs, being greater in MA1 with respect to MA2, and MA2 with respect to MA3. Linear regression found an association between age (years) and income per capita (US dollars/day/person) $\left(p<0.001, \mathrm{r}^{2}=0.1\right.$ after exclusion of three outliers): $35.7 \%$ (143/401) of children from 0-19 years of age were living in poverty, compared to only $14.2 \%(97 / 685)$ of adults (20 years or older) (OR: 3.36; 95\% CI: 2.50- 4.52; $p<0.001$ ). IPI frequency was not different among those enrolled in Bolsa Família (a government assistance program for families living in poverty) or between residents with different educational attainment levels. Bolsa Família was being received by $21.7 \%(72 / 317)$ of the families. Furthermore, employment status was not associated with IPIs, however women were significantly less likely to be employed (OR: 0.26; 95\% CI: 0.19- 0.36; $p<0.001$ ). Overall, $63.0 \%$ (373/592) of adults from 20-59 years of age were employed as well as $23.3 \%$ (42/180) of senior citizens (60 years or more). Linear regression found a negative association between employment among 20-59 year-old participants and employment among senior citizens $\left(r^{2}=0.98\right)$. No statistically significant association was detected between poverty and employment among senior citizens; yet, interviews found that employment among the elderly was based on family needs necessity and it was common social practice for grandparents to be the guardians of grandchildren. Giardia intestinalis was more common among children 0-9 years of age (OR: 4.95; 95\% CI: $1.96-12.40 ; p<0.001)$. Endolimax nana was more frequent among adults 20-59 years of age $(p=0.04)$ and 
Table 2 - Frequency distribution of residents, households and peridomiciliary characteristics by Major Area (MA) of Brazilian urban slums (Complexo de Manguinhos, Rio de Janeiro), n (\%)

\begin{tabular}{|c|c|c|c|c|c|c|c|c|c|}
\hline \multirow[t]{2}{*}{ Characteristics } & \multicolumn{5}{|c|}{ Major Areas } & \multirow[b]{2}{*}{ Total } & \multicolumn{3}{|c|}{$\begin{array}{c}\text { Intestinal parasitic } \\
\text { infections }\left(n_{4}\right)\end{array}$} \\
\hline & 1 & 2 & 3 & 4 & 5 & & $p$ & [Positive/Total] \% & $p$ \\
\hline $\operatorname{Sex}\left(n_{1}\right)$ & & & & & & & 0.27 & & 0.32 \\
\hline Male & $82(47.1)$ & $151(49.8)$ & $42(40.0)$ & $183(42.9)$ & $104(47.1)$ & $562(45.7)$ & & {$[81 / 257] 31.5$} & \\
\hline Female & $92(52.9)$ & $152(50.2)$ & $63(60.0)$ & $244(57.1)$ & $117(52.9)$ & $668(54.3)$ & & [94/338] 27.8 & \\
\hline Age $\left(n_{1}\right)$ & & & & & & & 0.06 & & 0.98 \\
\hline $0-9$ & $24(13.8)$ & $64(21.1)$ & $17(16.2)$ & 79 (18.5) & 44 (19.9) & $228(18.5)$ & & {$[32 / 76] 29.6$} & \\
\hline $10-19$ & $29(16.7)$ & $60(19.8)$ & $20(19.1)$ & $69(16.2)$ & $45(20.4)$ & $223(18.1)$ & & {$[22 / 53] 29.3$} & \\
\hline $20-59$ & $90(51.7)$ & $153(50.5)$ & $55(52.4)$ & $201(47.1)$ & $100(45.3)$ & $599(48.7)$ & & [85/198] 30.0 & \\
\hline$\geq 60$ & $31(17.8)$ & $26(8.6)$ & $13(12.4)$ & $78(18.3)$ & $32(14.5)$ & $180(14.6)$ & & [36/93] 27.9 & \\
\hline Residents/Household $\left(n_{1}\right)$ & & & & & & & 0.16 & & 0.30 \\
\hline $1-2$ & $22(12.6)$ & $34(11.2)$ & $9(8.6)$ & $54(12.6)$ & $19(8.6)$ & $138(11.2)$ & & {$[22 / 61] 26.5$} & \\
\hline $3-4$ & $73(42.0)$ & $108(35.6)$ & $35(33.3)$ & $181(42.4)$ & $95(43.0)$ & $492(40.0)$ & & {$[71 / 191] 27.1$} & \\
\hline $5 \leq$ & $79(45.4)$ & $161(53.1)$ & $61(58.1)$ & $192(45.0)$ & $107(48.4)$ & $600(48.8)$ & & [82/168] 32.8 & \\
\hline Poverty $\left(n_{2}\right)$ & & & & & & & $<0.001^{*}$ & & 0.58 \\
\hline Not in poverty & $153(91.6)$ & $146(67.6)$ & $69(65.7)$ & $321(83.2)$ & $157(74.1)$ & $841(77.4)$ & & {$[124 / 421] 29.5$} & \\
\hline Poverty & $14(8.4)$ & $57(26.4)$ & $36(34.3)$ & $65(16.8)$ & $47(22.2)$ & $164(15.1)$ & & {$[16 / 70] 22.9$} & \\
\hline Extreme poverty & $0(0.0)$ & $13(6.0)$ & $0(0.0)$ & $0(0.0)$ & $8(3.8)$ & $81(7.5)$ & & {$[5 / 12] 41.7$} & \\
\hline Educational attainment $\left(n_{3}\right)$ & & & & & & & 0.17 & & 0.88 \\
\hline $\begin{array}{l}\text { Illiterate or incomplete } \\
\text { elementary }\end{array}$ & $48(39.7)$ & $91(50.8)$ & $24(35.3)$ & $115(41.2)$ & $53(40.2)$ & $331(42.5)$ & & {$[59 / 197] 29.9$} & \\
\hline $\begin{array}{l}\text { Complete elementary or } \\
\text { higher }\end{array}$ & $66(54.5)$ & $79(44.1)$ & $42(61.8)$ & $156(55.9)$ & $75(56.8)$ & $418(53.7)$ & & {$[60 / 206] 29.1$} & \\
\hline No answer & $7(5.8)$ & $9(5.0)$ & $2(2.9)$ & $8(26.7)$ & $4(3.0)$ & $30(3.8)$ & & {$[2 / 7] 22.2$} & \\
\hline Employed $\left(n_{3}\right)$ & & & & & & & 0.04 & & 0.31 \\
\hline No & $55(45.4)$ & $72(40.2)$ & $31(45.6)$ & $130(46.6)$ & $69(52.3)$ & $357(45.8)$ & & {$[56 / 214] 26.2$} & \\
\hline Yes & $66(54.6)$ & $102(57.0)$ & $37(54.4)$ & $149(53.4)$ & $61(46.2)$ & $415(53.3)$ & & {$[64 / 194] 33.0$} & \\
\hline No answer & $0(0.0)$ & $5(2.8)$ & $0(0.0)$ & $0(0.0)$ & $2(1.5)$ & $7(0.9)$ & & {$[1 / 3] 25.0$} & \\
\hline Positive for intestinal parasites & {$[46 / 91]$} & {$[54 / 177]$} & {$[7 / 34](20.6)$} & [42/189] & {$[26 / 104]$} & {$[175 / 595]$} & $<0.001^{*}$ & - & - \\
\hline$\left(n_{4}\right)$ & $(50.5)$ & $(30.5)$ & & $(22.2)$ & $(25.0)$ & $(29.4)$ & & & \\
\hline Home ownership $\left(n_{5}\right)$ & & & & & & & 0.10 & & 0.14 \\
\hline Owned & $39(78.0)$ & $63(82.9)$ & $19(76.0)$ & $100(89.3)$ & $53(96.4)$ & $274(86.2)$ & & {$[161 / 523] 30.8$} & \\
\hline Rented & $11(22.0)$ & $12(15.8)$ & $6(24.0)$ & $11(9.8)$ & $2(3.6)$ & $42(13.2)$ & & {$[13 / 68] 19.1$} & \\
\hline Borrowed & $0(0.0)$ & $1(1.3)$ & $0(0.0)$ & $1(0.9)$ & $0(0.0)$ & $2(0.6)$ & & {$[1 / 4](25.0)$} & \\
\hline Flooring $\left(n_{5}\right)$ & & & & & & & 0.32 & & 0.91 \\
\hline Ceramic & $48(96.0)$ & $69(90.8)$ & $24(96.0)$ & $104(92.9)$ & $51(92.7)$ & $296(93.1)$ & & [161/547] 29.4 & \\
\hline Concrete & $1(2.0)$ & $7(9.2)$ & $1(4.0)$ & $6(5.4)$ & $2(3.6)$ & $17(5.3)$ & & {$[10 / 34] 29.4$} & \\
\hline Wood & $0(0.0)$ & $0(0.0)$ & $0(0.0)$ & $2(1.8)$ & $2(3.6)$ & $4(1.3)$ & & {$[3 / 12] 25.0$} & \\
\hline Dirt & $1(2.0)$ & $0(0.0)$ & $0(0.0)$ & $0(0.0)$ & $0(0.0)$ & $1(0.3)$ & & {$[1 / 2] 50.0$} & \\
\hline Water source $\left(n_{5}\right)$ & & & & & & & 0.00 & & 0.10 \\
\hline Canalized & $43(86.0)$ & $62(81.9)$ & $6(24.0)$ & $34(30.4)$ & $40(72.7)$ & $185(58.2)$ & & {$[115 / 360] 31.9$} & \\
\hline Mineral water & $7(14.0)$ & $10(13.2)$ & $19(76.0)$ & $77(68.7)$ & $15(27.3)$ & $128(40.2)$ & & {$[55 / 224] 24.5$} & \\
\hline Other & $0(0.0)$ & $4(5.3)$ & $0(0.0)$ & $1(0.9)$ & $0(0.0)$ & $5(1.6)$ & & {$[5 / 11] 45.4$} & \\
\hline Toilet $\left(n_{5}\right)$ & & & & & & & 0.67 & & 0.73 \\
\hline Inside & $50(100.0)$ & $74(97.4)$ & $25(100.0)$ & $111(99.1)$ & $54(98.2)$ & $314(98.7)$ & & [173/585] 29.6 & \\
\hline Outside & $0(0.0)$ & $2(2.6)$ & $0(0.0)$ & $1(0.9)$ & $1(1.8)$ & $4(1.3)$ & & {$[2 / 10] 20.0$} & \\
\hline Median total coliform bacteria & $1.6 \times 10^{7}$ & $4.0 \times 10^{6}$ & $1.0 \times 10^{6}$ & $6.1 \times 10^{6}$ & $5.6 \times 10^{6}$ & $5.0 \times 10^{6}$ & - & - & - \\
\hline (Interquartile range) & $\left(3.0 \times 10^{6}-\right.$ & $\left(5.3 \times 10^{5}\right.$ & $\left(6.7 \times 10^{5}-\right.$ & $\left(3.2 \times 10^{6}-\right.$ & $\left(1.4 \times 10^{6}\right.$ & $\left(1.1 \times 10^{6}\right.$ & & & \\
\hline & $\left.2.7 \times 10^{7}\right)$ & $\left.6.2 \times 10^{6}\right)$ & $\left.1.0 \times 10^{7}\right)$ & $\left.1.3 \times 10^{7}\right)$ & $\left.5.6 \times 10^{6}\right)$ & $\left.9.8 \times 10^{6}\right)$ & & & \\
\hline Median Escherichiacoli & $1.4 \times 10^{6}$ & $5.0 \times 10^{5}$ & $3.5 \times 10^{4}$ & $1.3 \times 10^{5}$ & $3.2 \times 10^{5}$ & $4.1 \times 10^{5}$ & - & - & - \\
\hline (Interquartile range) & $\left(9.0 \times 10^{4}-\right.$ & $\left(1.8 \times 10^{5}-\right.$ & $\left(3.5 \times 10^{4}-\right.$ & $\left(7.5 \times 10^{4}-\right.$ & $\left(3.2 \times 10^{5}\right.$ & $\left(7.0 \times 10^{4}-\right.$ & & & \\
\hline & $\left.1.5 \times 10^{6}\right)$ & $\left.2.5 \times 10^{6}\right)$ & $\left.3.5 \times 10^{4}\right)$ & $\left.1.6 \times 10^{6}\right)$ & $\left.3.2 \times 10^{5}\right)$ & $\left.1.3 \times 10^{6}\right)$ & & & \\
\hline
\end{tabular}


the employed (OR: 1.72; 95\% CI: 1.01- 2.94; $p=0.04$ ); however, logistical regression found that adulthood was a confounder. The presence of Entamoeba coli was different according to the source of drinking water, being higher when canalized piped water was used (OR: $1.81 ; 95 \%$ CI: $1.0-3.2 ; p=0.04)$.

Infection profiles identified from residents are shown in Table 3, including both profiles of mono- and polyparasitism. The commensal parasites E. nana and Entamoeba coli were the most frequently identified, with overall frequencies of $16.0 \%(95 / 595)$ and $10.9 \%$ (65 /595). G. intestinalis $(n=24 / 595,4.0 \%)$ and Ascaris lumbricoides $(n=11 / 595,1.8 \%)$ were the next most frequent agents detected. Coinfection with Entamoeba coli and E. nana was significant $(\mathrm{OR}=4.11 ; 95 \%$ CI: 2.35- 7.19; $p<0.001$ ). Coinfection with Entamoeba coli and Entamoeba histolytica/dispar appeared significant, however, logistical regression showed that this association was due to confounding factors and $E$. nana was associated with $E$. histolytica/dispar (OR=7.25; 95\% CI: 1.60-32.92; $p=0.01$ ). Coinfection with Entamoeba coli and A. lumbricoides was also significant $(\mathrm{OR}=4.90 ; 95 \%$ CI: $1.39-17.22 ; p=0.02)$.

All soil samples presented improper levels of both coliform bacteria and Escherichia coli, the greatest contamination was found in MA1 which presented a median measurement 533 times greater than the acceptable limit for total coliform bacteria and 36 times great than the limit for Escherichia coli permitted allowed by legislation ${ }^{26}$.

\section{DISCUSSION}

Globally, populations are increasingly urban and in Brazil $89.5 \%$ of the population is expected to be living in urban centers by 2020 , a major portion of this population in slums $^{27}$. Slums present a complex mixture of environmental, economic and social conditions which may affect IPIs ${ }^{3}$. In this study, the major areas (MA) differed significantly in terms of poverty and IPIs; however, the specific levels of poverty measured were not directly associated with IPIs in these communities where the overall conditions of poverty are pervasive. Poverty was associated with children, who are the target population of many studies regarding IPIs ${ }^{2,28}$. The method of determining poverty levels was limited due to its reliance solely on the income; however, even with this limitation and the heterogeneity of the communities, $22.6 \%$ of the total population was identified as living in poverty, highlighting the extremely high levels of poverty in this region.

Studies including the general population can analyze the interplay between poverty, age and parasitism. This study corroborates findings of $G$. intestinalis among children $^{13,29}$. Kiani et al. ${ }^{31}$ detected an inverse relationship between IPIs and age; however, in their study the role of age as a predictor for IPIs may have been confounded by employment, as detected with E. nana in this study. FIOCRUZ is a major employer of CM residents with most vacancies in janitorial and gardening services. Although type of employment was not verified, contact with soil has been found to increase the chance of infection and may be related to parasitism among the employed residents of MA1 (Table 1) ${ }^{14,31}$. Further studies among the employed participants are needed addressing their employment type and practices including the use of personal protective equipment like gloves and proper shoes. Urban farming, especially within marginalized slum communities, increases the chances of IPIs ${ }^{32}$; however, despite the presence of community gardens in MA2, this area did not have statistically significant difference in parasitism compared to the rest of the CM. This may be due to limited use of these gardens since interviews did not find residents who participated in community gardening. The areas with the highest risk of periodic flooding also did not have greater parasitism despite Sandoval et al. ${ }^{13}$ identified flooding as a predictor for IPIs. In the CM, with the exception of MA1, all areas are somewhat prone to flooding due to the history of the land (originally a mangrove swamp) and controversial public development projects which exacerbated flooding in some communities ${ }^{18}$. Although this study did not detect correlations, it is important to establish a baseline of infection profile in these communities and strengthen public health services that combat IPIs and mitigate the impact of these recurring events ${ }^{33}$.

Srinivasan et al. ${ }^{2}$ found an association between infection and lack of access to piped water. This was not seen in the $\mathrm{CM}$ because even with piped canalized water, like in similar studies, connections were generally clandestine, presenting leakages and no inspection of installation or maintenance ${ }^{21,34}$. Moraes Neto et al..$^{21}$ detected high levels of contamination of canalized piped water in other Brazilian slums, and in this study Entamoeba coli was associated with the utilization of canalized piped water, suggesting that canalization alone is insufficient for guaranteeing potable water. MA1 presented low usage of mineral water and interviews identified greater confidence in the canalized piped water quality and direct consumption of this water without other purification methods such as filters or boiling although all areas of the $\mathrm{CM}$ are connected to the same public water source. In addition, cases of parasitism in residents of MA1 were often among extended family members from different households. This finding is supported by Gil et al. ${ }^{29}$ who highlighted the importance of community contamination in addition to household 
Table 3 - Frequency distribution of intestinal parasites identified in residents of Brazilian urban slums (Complexo de Manguinhos, Rio de Janeiro), $n=595$

\begin{tabular}{|c|c|c|}
\hline Parasite Species & Frequency, n (\%) & Major Areas (MAs) detected \\
\hline Monoparasitism & $129(21.7)$ & $1,2,3,4,5$ \\
\hline Protozoa & & $1,2,4,5$ \\
\hline Entamoeba histolytica/dispar & $1(0.2)$ & 2 \\
\hline Entamoeba coli & $31(5.2)$ & $1,2,4,5$ \\
\hline Endolimax nana & $58(9.7)$ & $1,2,4,5$ \\
\hline lodamoeba butschlli & $1(0.2)$ & 1 \\
\hline Giardia intestinalis & $16(2.7)$ & $2,4,5$ \\
\hline Helminths & & $1,2,3,4,5$ \\
\hline Hymenolepis diminuta & $3(0.5)$ & 3 \\
\hline Strongyloides stercoralis & $2(0.3)$ & 4 \\
\hline Ascaris lumbricoides & $6(1.0)$ & 1,5 \\
\hline Trichuris trichiura & $4(0.7)$ & 1,2 \\
\hline Taenia sp. & $1(0.2)$ & 4 \\
\hline Ancylostomidae & $6(1.0)$ & $1,2,3,4$ \\
\hline Polyparasitism- 2 & $35(5.9)$ & $1,2,3,4,5$ \\
\hline Only protozoa & & $1,2,3,4,5$ \\
\hline Entamoeba coli \& E. nana & $17(2.9)$ & $1,2,3,4,5$ \\
\hline Entamoeba coli \& G. intestinalis & $2(0.3)$ & 4,5 \\
\hline Entamoeba coli \& I. butshlii & $2(0.3)$ & 1 \\
\hline E. nana \& E. histolytica/dispar & $3(0.5)$ & 2,4 \\
\hline E. nana \& G. intestinalis & $4(0.7)$ & $1,2,4$ \\
\hline E. nana \& I. butshlii & $1(0.2)$ & 5 \\
\hline Mixed infections & & $1,2,3,4$ \\
\hline Entamoeba coli \& A. lumbricoides & $2(0.3)$ & 1 \\
\hline Entamoeba coli \& T. trichuria & $1(0.2)$ & 3 \\
\hline E. nana \& Ancylostomidae & $1(0.2)$ & 1 \\
\hline E. nana \& A. lumbricoides & $1(0.2)$ & 4 \\
\hline E. nana \& S. stercoralis & $1(0.2)$ & 2 \\
\hline Polyparasitism- 3 & $11(1.8)$ & $1,2,4,5$ \\
\hline Only protozoa & & $1,2,4,5$ \\
\hline Entamoeba coli, E. nana, \& E. histolytica/dispar & $1(0.2)$ & 5 \\
\hline Entamoeba coli, E. nana, \& G. intestinalis & $1(0.2)$ & 2 \\
\hline Entamoeba coli, E. nana \& I. butshlii & $3(0.5)$ & 4,5 \\
\hline Entamoeba coli, I. butshlii, \& E. histolytica/dispar & $1(0.2)$ & 4 \\
\hline E. nana, E. histolytica/dispar, \& G. intestinalis & $1(0.2)$ & 1 \\
\hline Mixed infections & & 1 \\
\hline Entamoeba coli, A. lumbricoides, \& E. histolytica/dispar & $1(0.2)$ & 1 \\
\hline Entamoeba coli, E. nana, \& E. vermicularis & $1(0.2)$ & 1 \\
\hline Entamoeba coli, E. nana, \& H. diminuta & $1(0.2)$ & 1 \\
\hline Entamoeba coli, E. nana, \& A. lumbricoides & $1(0.2)$ & 1 \\
\hline Total infection frequency & $175(29.4)$ & - \\
\hline
\end{tabular}


factors. The relative superior living conditions of MA1, especially in terms of lower level of violence (an important characteristic of Brazilian urban slums), may lead residents not to acknowledge that their living conditions and health risks are shared with their neighbors in other MA which do present drug-related violence. However, this area presented the greatest measured environmental contamination and IPI prevalence.

Although the greatest prevalence was of commensal parasites, high prevalence of commensals has been found to be a predictor for pathogenic IPIs because they indicate the presence of fecal-oral transmission in the territory ${ }^{13}$. In this study, coinfections of E. nana with E. histolytical dispar and Entamoeba coli with A. lumbricoides were significant. Calegar et al..$^{35}$ found, after PCR analysis, that most infections with the morphologically indistinguishable E. histolytica/E. dispar complex were of the traditionally nonpathogenic E. dispar. Furthermore, even infections with pathogenic parasites were asymptomatic, suggesting that dependence solely on signs and symptoms of disease are insufficient for initiating treatment ${ }^{34-37}$. The collection and analysis of stool samples in urban slums covered by primary public health care services is necessary for establishing control measures to meet the community needs. Current guidelines for controlling IPIs are based almost exclusively on preventive chemotherapy despite the shifting profile of infection dominated by protozoa, such as the ones identified in the $\mathrm{CM}^{1,10}$. This change in profile may be attributed to the consumption of anthelmintics through self-medication, deworming campaigns and prescriptions through primary health services ${ }^{21}$. In the CM, complete coverage by the FHS could explain the low prevalence of IPIs, specifically of helminths. Another Brazilian study developed in an area covered by the FHS found that the frequencies of infection were much lower suggesting that, although the health services may contribute to low IPI frequencies, other factors are important for considering IPI vulnerability ${ }^{14}$. Although other methods such as PCR analysis may have detected greater IPI frequencies, the spontaneous sedimentation method used in this study has a sensitivity of $87.5 \%$ and a specificity of $99.1 \%$ when three slides per sample are analyzed and, as the method used in public services, it can be compared in local surveillance efforts ${ }^{24}$.

Health education and promotion initiatives developed by primary health services targeting or not targeting IPIs must consider the characteristics of these populations. Family dynamics in slum territories are complex and evolving, with employment status and income serving as important contributors to social relations. Home visits by the health professionals taking care of these communities are important for the understanding and the incorporation of lifestyle limitations imposed by the overall conditions of poverty.

\section{CONCLUSIONS}

It is important that both residents and health professionals consider the socioenvironmental conditions of urban slums when assessing intestinal parasitic infections for disease control and health promotion initiatives. This study showed that management of intestinal parasitic infections cannot be reduced in urban slums based on comparative estimates of need or a one-size-fits-all approach focusing on preventive chemotherapy for soil-transmitted helminths, since urban slums are complex socioenvironmental settings with interconnected needs. The changing profile of intestinal infections involves patient knowledge and practices in addition to community conditions. Health education, quality public sanitation (e.g. sewage collection and treatment, continued access to safe drinking water, regular trash collection), comprehensive health services acting in conjunction with other sectors (e.g. housing, education, transport, security) are required to address the needs of these communities.

\section{CONFLICT OF INTEREST}

The authors have no conflicts of interest to declare.

\section{ACKNOWLEDGMENTS}

We would like to thank the residents and the Family Health Strategy of the Complexo de Manguinhos, RJ, Rio de Janeiro. We would also like to thank Marli Tex for technical support, Dr. Arnaldo Maldonado-Júnior logistical support and infrastructure to perform laboratory diagnosis of stool samples in the Laboratório de Biologia e Parasitologia de Mamíferos Silvestres Reservatórios (LABPMR/IOC/FIOCRUZ) and the students of the Young Talents for Science Program (FAPERJ) from the Escola Técnica Estadual Juscelino Kubitschek for their invaluable support. This work would also not be possible without the support of Admilson dos Santos Martins de Farias and Edinso Rafael Mosquera Ruiz with the field work and logistical support.

\section{FINANCIAL SUPPORT}

Funding for this study was provided by: the Fundação Carlos Chagas Filho de Amparo à Pesquisa do Estado do Rio de Janeiro (FAPERJ) [Grant E-26/010.001915/2014 Edital ExtPesq 16/2014]; Financiadora de Estudos e Projetos 
(FINEP) [Accord FINEP/FIOCRUZ 01.11.0025.04, Rede Morar.Ts]; Vice-Presidência de Ambiente, Atenção e Promoção da Saúde (VPAAPS)/Vice-Presidência de Pesquisas e Laboratórios de Referência (VPPLR)/ Fundação Oswaldo Cruz (FIOCRUZ); the Instituto Oswaldo Cruz (IOC/FIOCRUZ); and the Coordenação de Aperfeiçoamento de Pessoal de Nível Superior (CAPES) [Accord FIOCRUZ/Ministério da Saúde /Ministério do Desenvolvimento Social - Edital "Brasil Sem Miséria"].

\section{REFERENCES}

1. World Health Organization. Soil-transmitted helminth infections: fact sheet. Geneva: WHO; 2016. [cited 2016 Jul 14]. Available from: http://www.who.int/mediacentre/factsheets/fs366/en/

2. Srinivasan P, Lawa HR, Rosado JL, Al Mamun A, Khatun M, Santos JI, et al. Household and personal factors are sources of heterogenity in intestinal parasite clearance among Mexican children 6-15 months of age supplemented with vitamin A and zinc. Acta Trop. 2016;156:48-56.

3. Sotero-Martins AS, Duarte AN, Carvajal E, Sarquis MI, Fernandes OC. Controle da qualidade microbiológica e parasitária em áreas de recreação. Gest Saude. 2014;5:2059-78.

4. World Health Organization. Global Health Estimates (GHE). Geneva: WHO; 2016. [cited 2016 Jul 14]. Available from: http://www.who.int/healthinfo/global_burden_disease/en/

5. Li XX, Zhou XN. Co-infection of tuberculosis and parasitic diseases in humans: a systematic review. Parasit Vectors. 2013;6:79.

6. Adekolujo DR, Olayinka SO, Adeniji JA, Oyeyemi OT, Odaibo $\mathrm{AB}$. Poliovirus and other enteroviruses in children infected with intestinal parasites in Nigeria. J Infect Dev Ctries. 2015;9:1166-71.

7. Azeredo-Coutinho RB, Pimental MI, Zanini GM, Madeira MF, Cataldo JI, Schubach AO, et al. Intestinal helminth coinfection is associated with mucosal lesions and poor response to therapy in American tegumentary leishmaniasis. Acta Trop. 2016;154:42-9.

8. Jejaw A, Zemene E, Alemu Y, Mengistie Z. High prevalence of Schistosoma mansoni and other intestinal parasites aong elementar school children in Southwest Ethiopia: a crosssectional study. BMC Public Health. 2015;15:600.

9. Brasil. Ministério da Saúde. Gabinete do Ministro. Portaria $N^{\circ}$ 204, de 17 de fevereiro de 2016. Define a Lista Nacional de Notificação Compulsória de doenças, agravos e eventos de saúde pública nos serviços de saúde públicos e privados em todo o território nacional, nos termos do anexo, e dá outras providências. [cited $2016 \mathrm{Jul} 12$ ] . Available from: http://bvsms. saude.gov.br/bvs/saudelegis/gm/2016/prt0204_17_02_2016. html

10. Brasil. Ministério da Saúde. Secretaria de Vigilância em Saúde.
Departamento de Vigilância das Doenças Transmissíveis. Plano integrado de ações estratégicas de eliminação da hanseníase, filariose, esquistossomose e oncocercose como problema de saúde pública, tracoma como causa de cegueira e controle das geohelmintíases: plano de ação 2011-2015. Brasília: Ministério da Saúde; 2012.

11. World Health Organization. Accelerating work to overcome the global impact of neglected tropical diseases: a roadmap for implementation. Geneva: WHO; 2012.

12. Turkeltaub JA, McCarty TR 3rd, Hotez PJ. The intestinal protozoa: emerging impact on global health and development. Curr Opin Gastroenterol. 2015;31:38-44.

13. Sandoval NR, Ríos N, Mena A, Fernández R, Perea M, ManzanoRomán R, et al. A survey of intestinal parasites including associated risk factors in humans in Panama. Acta Trop. 2015;147:54-63.

14. Casavechia MT, Lonardoni MV, Venazzi EA, Campanerut-Sá PA, Benalia HR, Mattiello MF, et al. Prevalence and predictors associated with intestinal infections by protozoa and helminths in Southern Brazil. Parasitol Res. 2016;115:2321-9.

15. Macchioni F, Segundo H, Gabrielli S, Totino V, Gonzales PR, Salazar E, et al. Dramatic decrease in prevalence of soiltransmitted helminths and new insights into intestinal protozoa in children living in the Chaco region, Bolivia. Am J Trop Med Hyg. 2015;92:794-6.

16. Hassen Amer O, Ashankyty IM, Haouas NA. Prevalence of intestinal parasite infections among patients in local public hospitals of Hail, Northwestern Saudi Arabia. Asian Pac J Trop Med. 2016;9:44-8.

17. Fiocruz. Escola Nacional de Saúde Pública Sérgio Arouca. TeiasEscola Manguinhos: Território Escola Manguinhos. [cited 2014 Aug 17]. Available from: http://andromeda.ensp.fiocruz.br/ teias/saudedafamilia.

18. Porto MF, Cunha MB, Pivetta F, Zancan L, Freitas JD. Saúde e ambiente na favela: reflexões para uma promoção emancipatória da saúde. Serv Soc Soc. 2015;123:523-43.

19. Instituto Brasileiro de Geografia e Estatística.Censo Demográfico 2010: CD 2010, questionário da amostra. [cited 2017 Mar 27]. Available from: http://censo2010.ibge.gov.br/images/pdf/ censo2010/questionarios/questionario_amostra_cd2010.pdf

20. Brasil. Ministério do Desenvolvimento Social e Combate à Fome. Cadastro Único para Programas Sociais: formulário principal de cadastramento. Brasília: Ministério do Desenvolvimento Social e Combate à Fome; 2011. [cited 2017 Mar 27]. Available from: http://www.servicos.gov.br/servico/cadastro-unico-paraprogramas-sociais-do-governo-federal

21. Moraes Neto AH, Pereira AP, Alencar MF, Souza PR Jr, Dias RC, Fonseca JG, et al. Prevalence of parasites versus knowledge, attitudes, and practices of inhabitants of low-income communities of Campos dos Goytacazes, Rio de Janeiro State, Brazil. Parasitol Res. 2010;107:295-307. 
22. Lutz A. O Schistosomum mansoni e a schistosomatose segundo observações, feitas no Brazil. Mem Inst Oswaldo Cruz. 1919;11:121-55.

23. Martins M, Lacerda MV, Monteiro WM, Moura MA, Santos EC, Saraceni V, et al. Progression of the load of waterborne and intestinal parasitic diseases in the State of Amazonas. Rev Soc Bras Med Trop. 2015;48 Suppl 1:42-54.

24. Tibiriçá SH, Abramo C, Simões AS, Pinheiro IO, Ribeiro LC, Coimbra ES. Validação do número de lâminas para realização do método de sedimentação espontânea das fezes. HU Rev. 2009;35:105-10.

25. Baermann G. Eine einfache Methode zur Auffindung von Ankylostomum-(Nematoden)-Larven In Erdproben. In: Baermann G. Mededelingen uit het Geneeskundig Laboratorium te Weltevreden. Batavia: Javashe Boekhandel \& Drukkerij; 1917. p. 41-7.

26. Rio de Janeiro. Secretaria Municipal de Meio Ambiente. Resolução No 468, de 28 de Janeiro de 2010. Dispõe sobre a análise e informações das condições das areias das praias no Município do Rio de Janeiro. Diário Oficial do Rio de Janeiro, 29 jan. 2010, ano 23, n 211. [cited 2015 Jul 23]. Available from: http://www.rio.rj.gov.br/dlstatic/10112/1458891/DLFE226002.pdf/Resolucao468de28012010.pdf

27. United States Agency International Development. Urbanization in Latin America and the Caribbean: trends and challenges. Washington, DC: USAID; 2010.

28. Osman M, El Safadi D, Cian A, Benamrouz S, Nourrisson C, Poirier $\mathrm{P}$, et al. Prevalence and risk factors for intestinal protozoan infections with Cryptosporidium, Giardia, Blastocystis and Dientamoeba among schoolchildren in Tripoli, Lebanon. PLoS Negl Trop Dis. 2016;10:e0004496.

29. Gil FF, Busatti HG, Cruz VL, Santos JF, Gomes MA. High prevalence of enteroparasitosis in urban slums of Belo Horizonte-Brazil. Presence of enteroparasites as a risk factor in the family group. Pathog Glob Health. 2013;107:320-4.

30. Ramos JM, Rodríguez-Valero N, Tisiano G, Fano H, Yohannes
T, Gosa A, et al. Different profile of intestinal protozoa and helminthic infections among patients with diarrhoea according to age attending a rural hospital in Southern Ethiopia. Trop Biomed. 2014;31:392-7.

31. Kiani H, Haghighi A, Rostami A, Azargashb E, Tabaei SJ, Solgi A, et al. Prevalence, risk factors and symptoms associated to intestinal parasite infections among patients with gastrointestinal disorders in Nahavand, Western Iran. Rev Inst Med Trop Sao Paulo. 2016;58:42.

32. Fuhrimann S, Winkler MS, Kabatereine NB, Tukahebwa EM, Halage AA, Rutebemberwa E, et al. Risk of intestinal parasitic infections in people with different exposures to wastewater and fecal sludge in Kampala, Uganda: a cross-sectional study. PLoS Negl Trop Dis. 2016;10:e0004469.

33. Pereira CA, Barata MM. Organização dos serviços urbanos de saúde frente à mudança do clima e ao risco de desastres na América Latina. Saúde Debate. 2014;38:624-34.

34. David EB, Guimarães S, de Oliveira AP, de Oliveira-Sequeira TC, Bittencourt GN, Nardi AR, et al. Molecular characterization of intestinal protozoa in two poor communities in the State of São Paulo, Brazil. Parasit Vectors. 2015;8:103.

35. Calegar DA, Nunes BC, Monteiro KJ, Santos JP, Toma HK, Gomes TF, et al. Frequency and molecular characterisation of Entamoeba histolytica, Entamoeba díspar, Entamoeba moshkovskii, and Entamoeba hartmanni in the context of water scarcity in northeastern Brazil. Mem Inst Oswaldo Cruz. 2016;111:114-9.

36. Castro ED, Germini MC, Mascarenhas JD, Gabbay YB, Lima IC, Lobo PS, et al. Pathogens detected in a daycare center, Southeastern Brazil: bacteria, virus, and parasite research. Rev Inst Med Trop Sao Paulo. 2015;57:27-32.

37. Cimino RO, Jeun R, Juarez M, Cajal PS, Vargas P, Echazú A, et al. Identification of human intestinal parasites affecting an asymptomatic peri-urban Argentinian population using multi-parallel quantitative real-time polymerase chain reaction. Parasit Vectors. 2015;8:380. 